\title{
ANNA CETERA-WŁODARCZYK
}

iD https://orcid.org/0000-0001-5711-4867

Uniwersytet Warszawski

a.cetera@uw.edu.pl

\section{"GENIUSZ DAJE TEMĘ, POETA JĄ WARIUJE", CZYLI O FRAPUJĄCEJ (NIE)MOŻNOŚCI REDAGOWANIA SZEKSPIRA W PRZEKŁADZIE ${ }^{1}$}

\section{Abstract}

"It takes a genius to set the tune, and a poet to know how to play variations on it": Some Remarks on the Irksome (Im)possibility of Editing Shakespeare in Translation

Drawing on the results of the research into the scale and distribution of Polish translation activity with regard to Shakespeare canon in the $19^{\text {th }}$ century, the article offers a discussion of the various roles assumed by both professional and informal (befriended) editors working with Shakespeare translators over time. Understandably enough, the editorial efforts serve to ensure the quality and reception of the text, and range from publisher's pressure and copyediting to aesthetic (or societal) patronage and complementary efforts to append the text with critical commentary. The article juxtaposes the intimacy of the translation process with the inherently intrusive role of an editor, foregrounding the fragile psychological balance which pre-conditions effective collaboration and longterm commitment. Finally, the article discusses the need of editorial policies attuned to Shakespeare in translation, which would take into account both the literary intricacy of the original(s) and the specificity of retranslation dialectics, with the necessary positioning of new rewritings against past canon(s).

Keywords: Shakespeare, translator studies, editorship, retranslation, critical editions

Słowa kluczowe: Szekspir, postać tłumacza, redakcja tekstu, retranslacja, wydania krytyczne

1 Artykuł powstał na kanwie wykładu wygłoszonego podczas Studenckich Warsztatów Tłumaczeniowych (Kraków, 9-11 maja 2017). Badania zostały sfinansowane ze środków Narodowego Centrum Nauki przyznanych decyzją 2015/17/B/HS2/01784 - grant „Repozytorium polskich przekładów dramatów Williama Shakespeare’a w XIX wieku: zasoby, strategie tłumaczenia i recepcja". 
W zbiorach National Gallery w Londynie znajduje się portret zatytułowany „Krawiec” (The Tailor). Dzieło powstało w latach 1570-1575 i wyszło spod pędzla włoskiego artysty Giovanniego Battisty Moroniego. Na pozór obraz ukazuje prozę rzemieślniczego żywota: ot, po prostu, przycinanie materiału. A jednak artyście udaje się uchwycić moment szczególny - chwilę namysłu tak intensywnego, że prosta czynność nabiera metafizycznego wymiaru. Krawiec Moroniego nie działa w uniesieniu: jego praca wymaga precyzji, tak aby wielkie, ciężkie nożyce przecięły materiał dokładnie tam, gdzie biegną oznaczone kredą linie. Współcześni interpretatorzy podkreślają często rewolucyjny wydźwięk malarstwa Moroniego, który portretując pełnych godności rzemieślników, rzucał wyzwanie podziałom klasowym, skutecznie utrwalanym przez komercyjną sztukę epoki. Niewykluczone, że sprawy rzeczywiście tak się miały w Bergamo, gdzie Moroni zasłynął jako portrecista. W Londynie jednak cała epoka elżbietańska sprzyjała niezwykłym awansom społecznym: arcydzieła teatru tworzyli tu przecież tacy parweniusze jak Marlowe - syn szewca, albo Shakespeare - syn rękawicznika. Ich talent rozkwitał na publicznej scenie, kunszt krawców - w karbach modeli i wymiarów. Namalowana przez Moroniego apoteoza skupienia oddaje w gruncie rzeczy etos zawodowy tych wszystkich, którzy w swojej pracy idą za jakimś wzorem - jak tłumacz, jak redaktor, jak krytyk.

\section{Nasz tłumacz Szekspira - czyli kto?}

Początek recepcji Szekspira w większości krajów europejskich przypada na czasy, które nie sprzyjają wydobywaniu takiego właśnie „rzemieślniczego” aspektu pracy nad tekstem. Szekspir zachwyca, kiedy wciąż jeszcze nie wiadomo, jak brzmi w języku przekładu. Fala bałwochwalczej fascynacji rozlewa się po Europie na długo, zanim przywędrują z Wysp teksty dramatów. To prawda, że teatr gra Szekspira od dziesięcioleci, ale „szekspiriady”, jak określał je Andrzej Żurowski (1976), nie są ani przyczyną, ani nawet objawem zbiorowego szaleństwa. Przekonanie o wielkiej wartości dramaturgii Szekspirowskiej poprzedza konfrontację odbiorców z tekstem, winduje też oczekiwania wobec tłumaczy. Jakiego tłumacza Szekspira życzy sobie dziewiętnastowieczna krytyka? Józef Przecławski, redaktor wpływowego onegdaj „Tygodnika Petersburskiego”, recenzując pierwsze polskie przekłady Szekspira, nie pozostawia w tej materii żadnych złudzeń i tylko poetom przyznaje prawo tłumaczenia geniuszy: 
Geniusz daje ton pieśni wieku... Geniusz zaczyna, współczesny poeta kontynuuje, bezdarny naśladownik idzie z tyłu i zbiera okruszyny; geniusz daje temę, poeta ją wariuje, naśladownik niezgrabnie w fałszywą całość splata wyśpiewanych już akordów urywki (Em. herbu Glaubicz 1840, cz. 1: 241).

Ta dziś nieco zabawna retoryka uniesień jest w gruncie rzeczy głęboko normatywna i bezwzględnie wartościująca. Tłumaczem geniusza może być tylko jednostka wybitna, znakomity poeta zdolny „wariować temę” i zespalać w harmonijne tony ,pieśni wieku”. W rozważaniach tych na próżno szukać jakkolwiek wyrażonej refleksji o ścierających się doktrynach estetycznych w obrębie kultury docelowej. Lecz któż połączy piękno i harmonię klasycyzmu z metafizyczną głębią i porywającą topiką romantyków? Kto nadto wprowadzi jakość całkiem nową, nieznaną w rodzimej literaturze, choć a priori tak przez nią podziwianą?

W tym wielkim czekaniu na przekłady Szekspira nie jesteśmy odosobnieni. W postnapoleońskiej Europie wiele krajów i narodów dookreśla swoją tożsamość, czyniąc z tłumaczenia arcydzieł miarę żywotności własnej literatury, zagrożonej lub dopiero co budzącej się do życia. Wielkie znaczenie mają tu doktryny niemieckie, formułowane w opozycji do modelu francuskiego, które w miejsce regresywnej definicji kultury jako skarbca przeszłości forsują koncepcję Bildung, a zatem kultury dynamicznej, otwartej, ekspansywnej, czerpiącej siłę z wchłonięcia i zasymilowania tego, co odmienne ${ }^{2}$. Oczekiwania epoki nabierają wyrazistości, kiedy natchnione myśli Przecławskiego osadzamy w bezpośrednim kontekście publikacji, a nawet więcej - starcia dwóch inicjalnych przekładów Romea i Julii.

W 1839 roku w Wilnie ukazał się pierwszy tom przekładów Ignacego Hołowińskiego, a w nim tłumaczenia właśnie Romea i Julii, a także Snu nocy letniej i Hamleta. Rok później konkurencyjny przekład Romea i Julii ogłosił Julian Korsak. Przekłady Hołowińskiego spowodowały silną polaryzację opinii $^{3}$. Z jednej strony cieszył już sam fakt pojawienia się tłumaczeń, z drugiej zdawało się, że teksty rozmijają się z tak długo pielęgnowanymi nadziejami. Krytykowano przede wszystkim niefrasobliwą, zmienną prozodię, która podważyła zaufanie również do innych aspektów przekładu. Z kolei Korsak

2 Por. znakomite studium Bermana (1992).

3 Szersze omówienie recepcji przekładów Hołowińskiego (recenzji, polemik, listów) można znaleźć w: Cetera 2009. Jego korespondencja z J.I. Kraszewskim jest również omawiana w: Budrewicz-Beratan 2005. 
do swego przekładu włączył fragment tłumaczenia Adama Mickiewicza ze sceny drugiej aktu II i, podobnie jak Mickiewicz, całość przełożył rymowanym trzynastozgłoskowcem. W czerwcu 1840 roku ukazała się w kolejnych dwóch numerach tygodnika obszerna, cytowana powyżej recenzja Romea i Julii w przekładzie Korsaka. Recenzja na pozór stawiała dokonania tego tłumacza na równi z przekładem Hołowińskiego, ale miażdżąca - jakoby „teoretyczna” - charakterystyka tłumaczenia „niewolniczego" wymierzona była w tego drugiego. Koniec końców, Przecławski życzyłby sobie przekładu, który zespoliłby geniusz Szekspira z geniuszem autora Dziadów.

Oczywiście opinia Przecławskiego - choć wpływowa - nie była jedyna. W sukurs Hołowińskiemu pospieszył młody Józef Ignacy Kraszewski, który z mocą opowiedział się po stronie przekładów przyjaciela jako wierniejszych ,prawdziwemu” Szekspirowi (Kraszewski 1840: 305). Najsilniejszego wsparcia udzielił mu jednak podówczas wpływowy krytyk koterii petersburskiej Michał Grabowski, który pisał:

[W] Kefalińskim [Hołowińskim] jest angielski Szekspir, z właściwą sobie fizjonomią, z nałogami, z akcentem mowy, po których go w każdej sztuce i w każdem miejscu sztuki, jak po znajomym głosie poznajemy (Grabowski 1843: 151).

Broniąc strategii Hołowińskiego, Grabowski nie zawahał się zakwestionować przekładu samego Mickiewicza:

Kiedy te słowa pisałem, nie wiedziałem, jakiej dopuszczam się zuchwałości; znając bowiem z poezji Pana Korsaka tylko wyjątki przytoczone w Tygodniku [Petersburskim], nie domyślałem się, że porównywam Kefalińskiego nie z Korsakiem, ale z Mickiewiczem (...) Nie poprawiam jednak mojej mimowolnej omyłki! (...) Wiersze te są zapewne bardzo piękne same w sobie, szczególnie według naszych wyobrażeń świetności i przesady (...) ale zbliżone do wierszy białych nowego tłumacza, odkrywają, że faktura Mickiewiczowska jest ubiorem i ubiorem nie do twarzy, prostej i nagiej poezji Szekspira (Grabowski 1843: 153).

Grabowski z mocą przyznawał, że Mickiewicz obdarzył polską poezję „genialną śmiałością, wdziękiem, rozmaitością, imaginacją, uczuciem” (154), ale wskazywał też na wartość poezji „tkwiącej w naturze”, surowej, niepoddanej misternej obróbce, za jaką uważał twórczość Szekspira: „[t]aką poezję w odłomach, w bryłach przenosić w sztukę, jest całkiem co 
innego, jak najszczęśliwiej, najświetniej poetyzować to lub owo" - kończył z przyganą (155).

Z opiniami Przecławskiego i Grabowskiego, zarówno wtedy, jak i dziś, można polemizować, nie w tym jednak rzecz. Ich osąd nie zasadzał się na drobiazgowych porównaniach z oryginałem, lecz odzwierciedlał zderzenie przekładu z poetyką kultury docelowej, a obie propozycje traktował jako mniej lub bardziej trafne z punktu widzenia dziewiętnastowiecznego wielbiciela Szekspira „w ciemno”. Również tłumacze często legitymizowali swoją pracę nad Szekspirem nie tyle biegłością warsztatową, ile siłą uczuć. Hołowiński swego autora opisywał tak:

Szekspir (...) jest to orzeł, co wzbiwszy się nad poziom, zdaje się być wszystkich czasów samowładnym królem i bierze wszędzie i wszystko, co napotka dobrego dla oddania swojej wysokiej myśli, nie troszcząc się bynajmniej o epokę, do której kaprysowie [kaprysów] odnosi swoją sztukę. Wielka to nauka zbierać ślady po drodze, którą geniusz przeleciał, albo patrzeć, jak zwalczał różne przeszkody (Dzieła Wilhelma Shakspeara... 1839: 481).

W listach zaś wyznawał:

Szekspir przemówił do mnie, pokochałem go z całej duszy, uczyniłem go moim światem, wspomnienia życia przywiązałem do jego przekładu i czytając teraz piękniejsze miejsca, przywodzę sobie na pamięć te jedynie szczęsne w moim życiu chwile, kiedy rad byłem $\mathrm{z}$ ich oddania ${ }^{4}$.

Spod sentymentalno-patetycznych deklaracji Hołowińskiego wyziera strategia przekładu czysto hermeneutyczna, oparta na dogłębnym przeniknięciu i rozpoznaniu intencji piszącego. Przeżywane w udręce i zachwycie braterstwo dusz stwarza właściwy kontekst pracy tłumacza i jest związkiem głębokim, intymnym i nieuchronnie zaborczym. Czy w tak zarysowanych relacjach jest miejsce dla kogoś trzeciego? A jeśli tak, jaką rolę miałby ów ktoś odgrywać?

${ }^{4}$ Korespondencja J.I. Kraszewskiego, BJ rkps 6456 IV, list z 11 listopada 1840 roku, k. $351 \mathrm{r}$. 


\section{Redaktor Szekspira - ale jaki?}

Paradoksalnie, mimo pozorów zamknięcia i egzaltacji, to właśnie historia pierwszych polskich przekładów Szekspira dostarcza kilku archetypów współpracy tłumacza z osobą pełniącą rozmaicie rozumiane funkcje redaktorskie. Pierwszy trop prowadzi do wydawnictwa.

\section{Archetyp pierwszy - „Pan Wydawca"...}

W miarę rozwoju rynku wydawniczego prawo autorskie i praktyka redakcyjna uporządkowały wiele zasad, w tym zakres oczekiwanej i dopuszczalnej ingerencji w publikowany tekst. Choć i dziś nieuchronnie iskrzy na poszczególnych etapach opracowania redakcyjnego przekładów, zwykle wiemy, kto i dlaczego sugeruje poprawki. W czasach debiutów przekładów Szekspira ortografia i interpunkcja leżały w gestii wydawcy, zdrowy rozsądek nakazywał jednak powstrzymanie się od ingerencji na większą skalę, na jaką uskarża się rozsierdzony Hołowiński:

Ten tom pierwszy wyszedł w czasie mojej niebytności w kraju, (...) nieoszacowany Pan Glücksberg przez zbytek dbałości o moją sławę (...) pozwolił sobie postąpić samowolnie z moim przekładem i zaraz na dorywcze zdanie Pana Wydawcy Tygodnika [Józefa Przecławskiego] uzbrojonego w elementarz, jak sam powiada, przechrzcił mój biedny Sen letniej nocy na jakąś cudzoziemską Wigilia S. Jana ${ }^{5}$.

Poprawki tego typu - a więc zmiany narzucane przez wydawcę - to odwieczne źródło sporu, również pomiędzy teoretykami edytorstwa, wśród których jedni chcieliby je identyfikować i oznaczać, drudzy restytuować pierwotne intencje twórcy, a jeszcze inni uważają je za spełnienie oczekiwań autora, oddającego manuskrypt do udoskonalającej obróbki redakcyjnej. W tym trzecim przypadku opublikowany tekst intepretowany jest jako świadectwo chwiejnej, lecz w tej właśnie postaci dla potrzeb druku ustabilizowanej równowagi sił między twórcą i wydawcą, a co za tym idzie - ważne źródło wiedzy o matrycach kulturowych, jakie oddziaływały na literaturę

5 Korespondencja J.I. Kraszewskiego, BJ rkps 6456 IV, list z 20 lutego 1840 roku, k. $328 \mathrm{r}$. 
i sztukę w danym okresie historycznym. Szorstkie relacje z „urzędową” redakcją bynajmniej nie oznaczają, że tłumacz nie odczuwa potrzeby udoskonalenia tekstu i nie szuka osób gotowych mu w tym pomóc. Ta właśnie uświadomiona potrzeba rodzi...

\section{Archetyp drugi, czyli „kiereszowanie rzęsiste”...}

Na gruncie prywatnym często dochodzi do współpracy intensywnej, o dużym znaczeniu dla kształtu tekstu, a jednocześnie w pewnej mierze ukrytej, nie licząc konwencjonalnych podziękowań za lekturę rękopisu. Tak było w wypadku Ignacego Hołowińskiego i Placyda Jankowskiego (znanego również jako John Dycalp), przyjaciela z okresu studiów w Wilnie, pisarza i thumacza Szekspira.

Relacja Hołowińskiego i Jankowskiego jest koleżeńska, swobodna i poufała, być może jednak zbyt wiele w niej dumy i ironii, aby wydała dobry owoc. Nie mamy wglądu w początki ich współpracy (nie zachowały się z tego okresu ani listy, ani rękopisy), dysponujemy za to rękopisem niewydanego przekładu Otella, w którym Jankowski nie tylko sugeruje szereg poprawek, ale całość kończy taką oto epistołą:

Daruj że się jeszcze raz wrócę do konia, na którym tak jeździć lubię: do miar Twoich. One mają jeszcze gorszą przywarę od naciąganych końcówek. Rymiki pospolicie w końcówkach śpiewają fistułą, a w twoich wierszach miarowych rzadko się obejdzie bez: nader nazbyt prawdziwie istotnie straszny ogromny niepomierny [podkreśl. aut.]. Zła i nudna to cecha, osłabia najpiękniejsze wiersze i nieraz zbliża tragiczność do śmieszności (...).

Nie kiereszowałem tak rzęsiście Murzyna jak sztuki dawniej czytane dlatego że pomimo przyzwolenia na moje poprawy, ty nic dobrego nie obracasz ich zysk na moją zbawienną korzyść. Przykład tego widziałem w Romeo i Julii. Niejedno miejsce rekomenduję $\mathrm{Ci}$ w tej sztuce do odmiany, i jaki los spotkał moje wykrzykniki i odsyłacze? Mów mi, jaki los spotkał moje wykrzykniki i odsyłacze! Moje wykrzykniki i odsyłacze! ${ }^{6}$

Zważywszy na dalsze losy przekładów Hołowińskiego, nie sposób odmówić Dycalpowi racji, gdy gromi szaleństwa prozodyczne kolegi. Końcowy komentarz - w zakresie, w jakim można wyciągać wnioski z tak niewielkiej

${ }^{6}$ Ignacy Hołowiński, Otello albo Murzyn z Wenecyi Shakspeara, Biblioteka Jagiellońska, rkps BJ 4211, k. 50 v. 
próbki - wskazuje jednak na inny, bardzo istotny aspekt współpracy, który dziś interpretowalibyśmy zapewne w kategoriach psychologicznych. Dycalp jest czytelnikiem kompetentnym, kolegą po fachu, sczytującym przekład $z$ oryginałem $w$ ręce. Jednocześnie staje się adwersarzem ironicznym, persyflażowym, gdy czuje, że tłumacz nie słucha jego dobrych rad. Zniechęcony odmawia dalszej pracy, a swoje pomysły realizuje w późniejszych własnych przekładach ${ }^{7}$. Urażony jest też zapewne Hołowiński, choć przecież sam słał rękopisy... Dziś można tylko zgadywać, czy przy nieco innym obustronnym nastawieniu pierwszy polski tłumacz Szekspira ogłosiłby więcej i lepszych przekładów. Niewątpliwie jednak zdawał sobie sprawę, że prócz koleżeńskiej lektury potrzebny mu mecenat innego rodzaju, prawdziwa przepustka na szersze wody literatury, a zatem...

\section{Archetyp trzeci, czyli „stosunki literackie”...}

Zachęcony pierwszą przychylną recenzją swych przekładów opublikowaną przez Kraszewskiego, Hołowiński pisał do niego tak:

Ale od dawna pragnąłem wejść w stosunki literackie z W[ielmożnym] Panem (...) miałbym sobie za grzech śmiertelny nie odezwać się do Pana: ach ja tych stosunków potrzebuję, nie tylko że u nas indywidualnie pracujący nie mogą nadać ogólnej dążności, lecz jeszcze pański młodzieńczy zapał mógłby mię budzić z często napadanego letargu, a wyższy sposób widzenia i wielostronna nauka, jakżeby wiele przyniosły korzyści dla moich ślęczeń i ramot! ${ }^{8}$

Opisanie wieloletniej przyjaźni obu pisarzy to temat na zgoła odrębną pracę, nie sposób też precyzyjnie odtworzyć wszystkich motywacji i emocji związanych z tą znajomością. Ważne wszakże jest to, że zabiegając o przychylność Kraszewskiego, Hołowiński szukał intelektualnego sojuszu: dostatecznie dufny, by odrzucać sugestie Dycalpa, nie czuł się jednak w kręgach literackich zbyt pewnie. Choć wspierało go środowisko wołyńsko-petersburskie, z Kresów wciąż jednak było bardzo daleko do warszawskich i krakowskich elit, nie wspominając już o paryskiej emigracji. „Stosunki literackie" były więc dla Hołowińskiego warunkiem powodzenia przedsięwzięcia, które bez przychylnych recenzji uznanych autorytetów osunęłoby

7 Po rezygnacji Hołowińskiego z przekładu Szekspira Placyd Jankowski ogłosił w latach 1842-1847 cztery własne tłumaczenia. Por. omówienia relacji Hołowińskiego i Jankowskiego w: Cetera 2009.

${ }^{8}$ Korespondencja J.I. Kraszewskiego BJ rkps 6456 IV, list z 20 lutego 1840 roku, k. 328. 
się w niebyt. Wiele lat później w podobny sposób polscy tłumacze będą zabiegać o aprobatę Jana Kotta, wybitnych artystów lub szacownych instytucji. Dynamika takich stosunków, lojalność, trwałość, takt są kluczowe dla powodzenia wielu przedsięwzięć przekładowych, zwłaszcza gdy tłumacze tracą wiarę w sens własnych poczynań lub gdy kontynuacja pracy wymaga zbyt wielu wyrzeczeń, również w sensie ekonomicznym. Smutną prawidłowością polskich przekładów Szekspira jest ich nieopłacalność, czego wymowne ślady można odnaleźć w listach Hołowińskiego, Paszkowskiego, Ulricha... Wsparcie, nawet niewielkie, grupki zdeklarowanych wielbicieli talentu jest więc w tym wypadku bezcenne. Wychodząc nieco poza ścisły krąg osób związanych z tłumaczem, natrafiamy na jeszcze jeden obszar, gdzie ważą się losy przekładów. Przyznawany a priori status arcydzieła to zbyt mało, aby tekst istotnie zadomowił się w kulturze docelowej. Pisze o tym jeden z recenzentów, wprowadzając w ten sposób...

\section{Archetyp czwarty - „ścisły rozbiór"...}

Zarzuty wobec niedopracowanej edycji bywały surowe:

Uderza nas przede wszystkim brak prawie zupełny ścisłego rozbioru sztuk ogłoszonych. Nie chodzi nam tu wcale o wykazanie pojedynczych piękności, bo te odkryje każdy czytelnik choć jedną kropelką poetycznego uczucia obdarzony, ale o ogólny pogląd na cudowną ekonomię każdego w szczególności dramatu (...). Zdaniem naszem podobnego rodzaju praca jest nieodzowną przy każdym nowym thumaczeniu Szekspira (Dzieła W. Shakespeare..., 1849: 409).

Choć wydaje się, ze oczekiwania te są oczywiste, rzut oka na polskie wydania Szekspira dowodzi, że postulat ten przychodzi nam realizować z wielkim trudem. Czy rzeczywiście Szekspir jest pisarzem tak uniwersalnym, że nic nam po objaśnieniach? A może tak „współczesnym”, że wszystkie interpretacje są doraźne, przemijające i koniec końców niewarte spisywania? Niechęć do edycji z rozbudowanym aparatem naukowym nie pozostaje bez wpływu na strategie przekładu. W pewnym sensie wymusza ona silnie udomowione przekłady, przerzucając na tłumacza funkcję komentatora, objaśniacza tekstu, który z braku innych możliwości co rusz sięga po ekwiwalencję dynamiczną, interpoluje wskazówki interpretacyjne lub wypuszcza fragmenty nadmiernie obciążone odniesieniami kulturowymi. Gdy tendencja ta przechodzi w konwencję, wydawcy preferują teksty 
„czyste”, „literackie”, transparentne, wolne od przypisów. Gdy do tego dodać presję teatru i cenioną przez aktorów czystość illokucyjną, kwestia strategii przekładu dramatu zdaje się w dużej mierze przesądzona. Niechętna edycjom krytycznym polityka akademicka i wydawnicza źle świadczy o naszych czasach, zaprzepaszcza też tradycje dziewiętnastowieczne, kiedy to liczne wstępy i posłowia tyle służyły Szekspirowi, co odmalowywały obraz epoki z jej metodologią, etyką i estetyką. Co ważne, edycje krytyczne wypracowują przestrzeń wokół utworu, strefę buforową, w której tłumacz nie musi podejmować desperackich działań, aby zniwelować (lub ukryć) dystans kulturowy. Bywa, że to właśnie obecność krytyka-literaturoznawcy przywraca tłumaczowi swobodę działania i zachęca do podejmowania ryzyka w miejscach, których specyfika zostanie przez kogoś innego objaśniona. Właśnie o takiego partnera zabiegał od początku Hołowiński.

Rozszerzając perspektywę na kilkudziesięciu pozostałych tłumaczy Szekspira w XIX wieku, odkrywamy uderzającą powtarzalność zarysowanych sytuacji i układów ${ }^{9}$. Okolicznością sprzyjającą decyzji o przystąpieniu do tłumaczenia bywa też często osobiste nieszczęście, które w dramatyczny sposób odizolowuje przyszłego tłumacza od rodziny, społeczności lub nawet kraju. Tak dzieje się w przypadku zesłania lub przymusowego przesiedlenia (na przykład Gustaw Ehrenberg, Adam Pług, Józef Korzeniowski), emigracji (Leon Ulrich, Krystyn Ostrowski) lub choroby (Władysław Matlakowski, Józef Paszkowski). Szersza perspektywa ukazuje także powtarzalność schematów wydawniczych: próby ustanowienia serii i problemy z utrzymaniem tempa pracy, tłumaczenia wydawane własnym sumptem, a następnie rozproszone i pominięte przez krytykę i teatr. Często po dobrym przyjęciu w czasach współczesnych następuje zapomnienie w kolejnych dekadach i dopiero zestawienie przedsięwzięć udanych i nieudanych pozwala w pełni ocenić, jakie czynniki zdecydowały o sukcesie tych pierwszych i porażce tych drugich. Nawiasem mówiąc, nawet bez rozbudowanego aparatu nowego historyzmu analiza materiałów wypchniętych z głównego nurtu recepcji bywa źródłem cennej wiedzy o epoce. Poszerzone studia uwidaczniają też wewnętrzną dynamikę rozlicznych środowisk, które udzielały tłumaczom wsparcia i przyczyniały się do utrwalenia ich pracy. W każdym przypadku środowiska te realizowały różnie pojmowane archetypy redaktorskie.

9 W XIX wieku było około trzydziestu tłumaczy Szekspira. Liczba ta nie uwzględnia tych, którzy pozostawili teksty w rękopisie lub ogłosili jedynie fragmenty swoich przekładów. 


\section{Przekład kanoniczny czy kanon przekładów?}

Trudno sobie wyobrazić, że współczesny redaktor Szekspira w przekładzie jest akuszerem i komentatorem jednego tylko tłumaczenia. Z upływem wieków translacje i retranslacje tworzą przecież odrębny korpus tekstów, które oprócz oczywistej funkcji odwzorowywania oryginału wpływają na teksty mające dopiero powstać. W przypadku dzieł tłumaczonych wielokrotnie na przestrzeni stuleci ten właśnie cykl przekładów, ich diachroniczny rozwój, staje się źródłem wiedzy o niegdysiejszych poetykach, a także rzecz niebagatelna - o intertekstualnej dialektyce retranslacji. Zakodowane w kolejnych odsłonach tekstu obrazy rzeczywistości to (wszech)świat nie tylko Szekspira, lecz również każdej kolejnej epoki. Jakie wnioski płyną z porównania obrazów utrwalonych w takich kroplach przekładowej żywicy?

Przyjrzyjmy się raz jeszcze, już bez romantycznych emocji, fragmentowi przekładu Romea i Julii, który tak poróżnił dziewiętnastowiecznych krytyków. Miejsce bezpośredniego starcia to monolog Romea podziwiającego Julię na balkonie na tle rozgwieżdżonego nieba. W przekładzie Mickiewicza fragment ten brzmi tak:

Lecz stójmy! co tam w oknie błysnęło zarazem.

To wschód słońca, a słońcem są Julii lica; (...)

Dwie gwiazdy w pilnej kędyś posłane potrzebie,

Proszą oczu Julii, by raczyły w niebie

Świecić, nim gwiazdy wrócą i znowu zaświecą.

I cóż jeśli jej oczy do niebios ulecą?

I cóż jeżeli gwiazdy błysną śród jej czoła?

Blask Julii oblicza gwiazdy zaćmić zdoła,

Jako dzień gasi lampy; a niebo jej okiem

Powietrzną jasność takim lałoby potokiem,

Ze ptaki dzień w omylnym witałyby dźwięku.

(Korsak 1840: 51)

Gdy wsłuchać się w znajome metrum, aż kusi, aby dorzucić pointę: „Tu przerwał, lecz róg trzymał; wszystkim się zdawało, / Że Wojski wciąż gra jeszcze, a to echo grało"... Bo czyż nie tak właśnie mógłby Tadeusz zachwycać się Zosią, gdyby dano mu było ujrzeć ją nocą pod włoskiem niebem, nie zaś w pstrokatym ogródku w Soplicowie? Wiersze Szekspira/ Mickiewicza/Korsaka płynną lekko, rytmicznie, z idealnie wpasowanymi 
okresami retorycznymi. „Lecz stójmy” - woła Romeo, jakby zapraszał do ogrodu Kapuletów publiczność, której o swym kochaniu z wdziękiem opowie. Romeo Hołowińskiego jest raczej sam („Cicho!”) i od razu wpada w karkołomną sekwencję nieludzko ściągniętych form gramatycznych:

Cicho! przez okno blask jakiś pada!

Wschódże-to piękny, Juliaż słońce! (...)

Dwie najpiękniejsze gwiazdy na niebie

Mając odjechać w pilnej potrzebie,

Proszą jej oczu, nim wrócą z jazdy

Aby świeciły w górnej ich sferze.

Gdy oczy w niebie, w jej twarzy gwiazdy

Chciałyby mieszkać: gwiazdom odbierze

Blask ich ze wstydem Julii lice,

Jako dzień lampie; z jej oczu w niebie

Strumień światłości zleje się taki,

Że oszukane ozwą się ptaki,

Jakby witały słońce przy wschodzie.

(Dzieła Wilhelma Shakspeara... 1839: 255)

Nawet jeśli uznać watowany trzynastozgłoskowiec Mickiewicza za przekładowe nadużycie, rozchwiany dziesięciozgłoskowiec Hołowińskiego również nie wzbudza zaufania. Pominąwszy prozodię, warto zauważyć, że oryginalny monolog Romea niesie pewien fantastyczny obraz, który w przekładzie łatwo zniekształcić:

But, soft! what light through yonder window breaks?

It is the east, and Juliet is the sun. (...)

Two of the fairest stars in all the heaven,

Having some business, do entreat her eyes

To twinkle in their spheres till they return.

What if her eyes were there, they in her head?

The brightness of her cheek would shame those stars,

As daylight doth a lamp; her eyes in heaven

Would through the airy region stream so bright

That birds would sing and think it were not night.

(Shakespeare 2003: II 2.2-3, 15-22)

W XVI wieku konwencja uczyniła ze zmysłowych wyznań surowiec poezji. Szekspir dobrze wiedział o zużyciu języka miłości, kiedy tworzył postaci 
zakochanych nastolatków. W wyznaniach Romea aż roi się od sonetowych klisz, dopiero z czasem ustępujących miejsca poezji prostej, zwartej, silnej, w której rządzi Eros i Tanatos. Przez większość sztuki jednak zakochani mówią językiem zasłyszanym, manierystycznym, czasem śmiesznym, choć ów komediowy swing nie zawsze jest właściwie rozpoznany przez tłumaczy i krytyków. Migocące w kosmosie oczy Julii to czyste szaleństwo, ale Romeo opisuje owe dziwaczne zjawisko w miarę fachowo, świadomy budowy ptolemejskiego wszechświata, w którym planety muszą opuścić krystaliczne sfery, aby ich miejsce mogły zająć roziskrzone oczy dziewczyny. Pomysł Romea jest niedorzeczny, ba - monstrualny, i dowodzi jedynie, że rozpalona wyobraźnia mąci zakochanemu w głowie. Fragment ten wpisuje się natomiast w istotny ciąg intratekstualnych odwołań do gwiazd, z których każde, począwszy od słynnego prologu, niesie zapowiedź katastrofy ${ }^{10}$. Co więcej, nawet pominąwszy inne złowrogie przepowiednie, sam obraz - wywrócony na nice - straszy widmem śmierci z pustymi oczodołami. Takie nagłe, proleptyczne rozchylenie zasłony, przebłysk przyszłości, to rozpoznawalny chwyt dramatyczny Szekspira, do perfekcji doprowadzony w Makbecie, choć tam brak odniesień astronomicznych. W Romeo i Julii akcja toczy się w świecie rządzonym przez złe gwiazdy, które sprowadzają nieszczęście, a konkretnie - dżumę.

Za życia Szekspira dżuma pustoszy Anglię kilkakrotnie, a jedna z największych epidemii panuje w latach 1593-1594, tuż przed wystawieniem Romea $i$ Julii $^{11}$. Zaraza budzi paniczny strach, jej ofiarą padają dziesiątki tysięcy ludzi: w 1563 i 1603 roku co czwarty mieszkaniec Londynu. O tej największej traumie owych czasów Szekspir nie wspomina w swoich fabułach - z wyjątkiem Romea $i$ Julii: to właśnie nagły wybuch dżumy sprawia, że posłaniec $\mathrm{z}$ wieścią o pozorowanej śmierci Julii utknie po drodze z Werony w mieście objętym kwarantanną. Elżbietanie nie wiedzą, co jest przyczyną choroby: może przynosi ją wilgotne powietrze, może złowróżbne układy gwiazd. Lęk wzmaga wrażliwość na znaki przyrody, nic więc dziwnego, że gdy Romeo opisuje znikające ze sfery planety i noc jak dzień jasną, publiczność przeczuwa nieszczęście ${ }^{12}$. W przekładzie Mickiewicza jakieś

${ }^{10}$ Por. słynne określenie Romea i Julii z prologu sztuki - a pair of star-crossed lovers (Shakespeare 0.6), w jednym z możliwych przekładów - para kochanków, którym gwiazdy były przeciwne.

${ }^{11}$ W czasie epidemii teatry były zamknięte. Zakłada się, że wydrukowaną w 1597 roku sztukę grano w lecie 1596 roku.

12 Dla rozbudzenia wyobraźni podczas wykładu odtworzyliśmy widok nieba nad Londynem w czerwcu 1596 roku, kiedy prawdopodobnie wystawiano Romea i Julię. Symulacja 
„dwie gwiazdy” podróżują „kędyś” po niebie, oczy zaś - jak dusza - „do niebios" ulatują, zacierając tym samym ślad po koncepcji kosmosu, która jest podstawą Szekspirowskiego obrazu. Paradoksalnie, to oszczędzający na sylabach Hołowiński każe, jak Szekspir, najpiękniejszym gwiazdom (Wenus? Marsowi?) zniknąć ze swych sfer, utrzymując kosmiczne szaleństwo Romea w karbach współczesnego mu paradygmatu budowy świata ${ }^{13}$.

\section{Czy można Szekspira (prze)redagować?}

Niewątpliwie wizja przekładu Szekspira oplecionego gąszczem przypisów, w dybach wstępów i komentarzy może zniechęcać do lektury. Szkopuł w tym, że Szekspir sauté to iluzja przystępności oparta między innymi na przekonaniu, że dobry przekład wytłumaczy wszystko, o czym długo i zawile piszą literaturoznawcy. Rola redaktora Szekspira polega przede wszystkim na objaśnianiu natury tekstu, współpracy z tłumaczem, wreszcie osadzeniu przekładu w kulturze docelowej, zarówno dawnej, jak i współczesnej.

Pierwsze ze zadań jest wyjątkowo trudne, zwłaszcza gdy w kulturze docelowej nie ma tradycji omawiania tego typu zagadnieńn ${ }^{14}$. Bardzo niewiele sztuk Szekspira zachowało się w jednej tylko wersji, a i te poddawane są rozmaitym emendacjom z uwagi na domniemane błędy drukarskie, pomyłki skrybów i tym podobne. Praca angielskich edytorów wymaga zwykle ustalenia tekstu najbliższego pierwotnej podstawie druku (copy-text), co oznacza żmudne lawirowanie między zachowanymi wczesnymi wersjami (drukowanymi), które z kolei wywodzą się z rękopisów o rozmaitym statusie i pochodzeniu (są wśród nich bruliony autorskie lub ich kopie, egzemplarze suflerskie, rekonstrukcje z pamięci, przeróbki itp.). Ten wielowiekowy wysiłek edytorów obejmuje wszystkie poziomy tekstu: podział na akty i sceny, spis osób, nagłówki dialogów, didaskalia, ortografię i interpunkcję, prozodię, wreszcie selekcję wariantów leksykalnych i interpretacyjnych. Jednocześnie ta sama tradycja redakcyjna jest w ostatnich dziesięcioleciach przedmiotem

komputerowa ukazała koniunkcję Marsa i Wenus w pobliżu zawsze złowrogiego Saturna. Taki widok mógł budzić niepokój.

${ }_{13}$ Na podobne przesunięcia natrafiamy też w nowszych przekładach: u Iwaszkiewicza gwiazdy odchodzą „w przestrzeń”, u. Barańczaka - schodzą „z orbit”, co jest w dodatku pojęciowym anachronizmem.

14 Wyjątkiem są tu przekłady Hamleta za Quarto 1 - Kydryńskiego (1987) i za Quarto 2 i Folio - Chwalewika (1975). Kwestie podstawy thumaczenia omawiane są we wszystkich tomach przekładów Szekspira pióra Piotra Kamińskiego. 
silnej kontestacji w ramach tak zwanego rewizjonizmu edytorskiego. Doktryna ta, po pierwsze, nakazuje szacunek dla integralności zachowanych wersji (wszak różnice między nimi mogą wynikać nie z błędów transmisji, lecz chociażby z ewoluującej wizji sztuki przeredagowywanej przez samego autora), po drugie zaś, nalega na cofnięcie wielu emendacji wprowadzonych w wyniku nazbyt purystycznego podejścia do tekstu Szekspirowskiego, na przykład uznawania rozmaitych odstępstw od reguł prozodycznych za błędy kopistów. Trzeci impuls do zmian pochodzi z obszaru badań nad autorstwem (w tym badań wspomaganych komputerowo, analiz stylometrycznych itp.). Tu rezultatem jest silniejsze wyeksponowanie udziału „obcej ręki” w dramatach Szekspira, jak również dowodzenie jego udziału w sztukach napisanych we współpracy, co prowadzi między innymi do wydawania w prestiżowej serii The Arden Shakespeare takich sztuk jak The Two Noble Kinsmen (1997), Double Falshood (2010) i Thomas More (2011).

Bez wątpienia nie wszystkie dylematy anglosaskich edytorów podzielają redaktorzy przekładów Szekspira. W tłumaczeniu dochodzi do neutralizacji wariantów ortograficznych czy interpunkcyjnych; co więcej, przekłady cechuje zwykle większa regularność metryczna, a także inflacja, czyli dodawanie wersów. Brak wydań krytycznych skutkuje w pewnym sensie utajnieniem tej problematyki wśród odbiorców, nieświadomych tego, jak złożona jest proweniencja oryginału i jak eklektyczna jest podstawa, z której korzysta tłumacz, konstruując swój przekład.

Drugi obszar aktywności redaktora to bezpośrednia współpraca $\mathrm{z}$ tłumaczem. Krytyczna lektura przekładu może obejmować sprawdzenie poprawności semantyki czy prozodii, w każdym jednak przypadku powinna się opierać na znajomości oryginału, a także na lekturze innych przekładów, z czego część tłumaczy rezygnuje, aby uniknąć podobieństw lub nie sugerować się cudzą interpretacją. Sczytując przekład, warto sprawdzić spójność postaci, wyodrębniając $\mathrm{z}$ dramatu poszczególne role, jak czynią to aktorzy. Duże znaczenie ma wychwycenie wszelkich inter- i intratekstulaności, tak aby utrzymać ciągi nawiązań obecne w oryginale i rozmontować te powstałe przypadkowo w trakcie tłumaczenia. Korzystne bywają też kombinacje rozmaitych komplementarnych umiejętności tłumacza i redaktora. Tak się dzieje, kiedy na przykład redaktor ma wyobraźnię plastyczną, przechodzącą płynnie od tekstu do obrazu, tłumacz zaś przywiązuje większą wagę do eufonii, uprzywilejowując brzmienie i rytm. Kluczowe jest zawsze uszanowanie estetyki czy też ogólnej strategii tłumacza, tak aby przekład zachował cechy autorskie, bez narzucania jakichkolwiek rozwiązań. 
Trzeci obszar działań edytorskich to osadzenie przekładu w kulturze docelowej, dawnej i współczesnej. Opracowania takie wobec wielowiekowej recepcji powinny również obejmować historię przekładów, bez których nie była przecież możliwa recepcja teatralna i krytyczna.

Historia każdego przekładu jest unikatowa, niezmienne natomiast wydają się reguły retranslacji. Żaden przekład nie zastępuje oryginału w sposób ostateczny. Z kolei przekłady odrzucone przez swoją epokę pozostają poza głównym nurtem recepcji, choć mogą współtworzyć nowe tłumaczenia. Brak edycji krytycznych wymusza strategie przekładu oparte na silnym udomowieniu tekstu, a także - z powodu fałszywego wyobrażenia o jednolitym stylu Szekspirowskim - niwelujące różnice stylu i rejestru, które cechują oryginały.

Zaniechanie edycji krytycznych jest objawem kryzysu humanistyki.

\section{Bibliografia}

Berman A. 1992. The Experience of the Foreign. Culture and Translation in Romantic Germany, przeł. S. Heyvaert, Albany: State University of New York Press (L'Épreuve de l'étranger. Culture et traduction dans l'Allemagne romantique, Gallimard 1984). Budrewicz-Beratan A. 2005. Dwugłos o Szekspirze: Józef Ignacy Kraszewski i Ignacy Holowiński, w: H. Bursztyńska (red.), Od strony Kresów. Studia i szkice. Część trzecia, Kraków: Wydawnictwa Naukowe Uniwersytetu Pedagogicznego, s. 53-61.

Cetera A. 2009. Smak morwy. U źródet recepcji przekładów Szekspira w Polsce, Warszawa: Wydawnictwa Uniwersytetu Warszawskiego.

Cetera-Włodarczyk A., Kosim A. 2009. Polskie przekłady Shakespeara w XIX wieku.

Czesść 1. Zawody, strategie, recepcja, Warszawa: Wydawnictwo Uniwersytetu Warszawskiego.

Dzieła Wilhelma Shakspeara [Williama Szekspira]. 1839. Przekł. Ignacy Kefaliński [Hołowiński], t. 1, Wilno.

Dzieła W. Shakespeare przekład J. Kefalińskiego. 1849. „Przegląd Poznański” 9, s. 395-416. Em. herbu Glaubicz [Józef Przecławski]. 1840. Nowe poezye Juljana Korsaka, „Tygodnik Petersburski" 46, s. 241 [cz. 1], i 47, s. 246-247 [cz. 2].

Grabowski M. 1843. O polskim tlumaczeniu Szekspira. Wyjątek ze studiów nad Szekspirem, „Rocznik Literacki”, s. 151-181.

Korsak J. 1840. Nowe Poezye [w tym przekład Romeo i Julia], t. 1, Wilno.

Kraszewski J.I. 1840. [Rozbiór Hamleta w przekładzie I. Hołowińskiego], „Tygodnik Petersburski" 58, s. 305-307.

Shakespeare W. 2003 [1984]. Romeo and Juliet, ed. G. Blakemore Evans. Cambridge: Cambridge University Press.

Żurowski, A. 1976. Szekspiriady polskie, Warszawa: PAX. 